
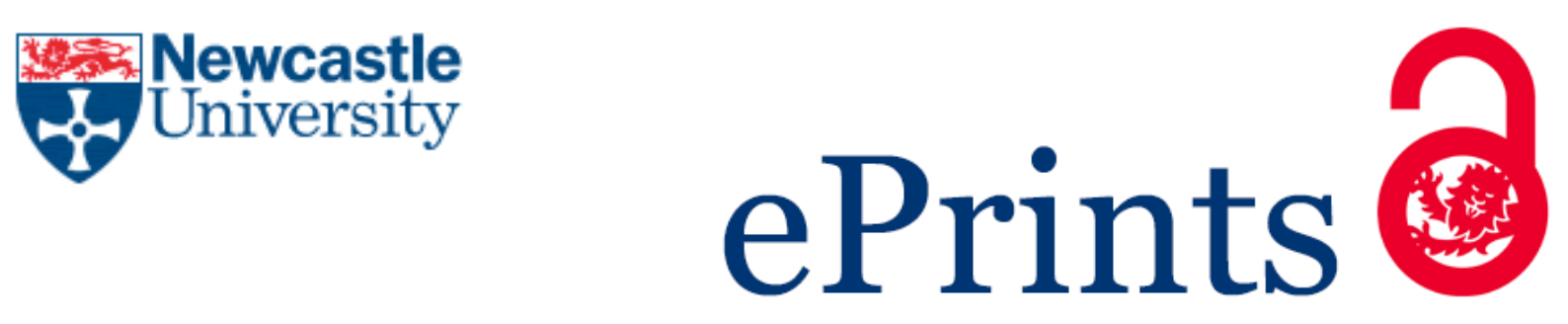

\author{
Gabbioneta C, Prakash R, Greenwood R. \\ Sustained corporate corruption and processes of institutional ascription \\ within professional networks. \\ Journal of Professions and Organization 2014, 1(1), 16-32.
}

\title{
Copyright:
}

This is a pre-copyedited, author-produced version of an article accepted for publication in Journal of Professions and Organization following peer review. The version of record Gabbioneta C, Prakash R, Greenwood R. Sustained corporate corruption and processes of institutional ascription within professional networks. Journal of Professions and Organization 2014, 1(1), 16-32. Is available online at: http://dx.doi.org/10.1093/ipo/jot002.

DOI link to article:

http://dx.doi.org/10.1093/jpo/jot002

Date deposited:

$21 / 02 / 2017$

Embargo release date:

06 January 2016

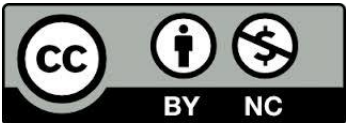

This work is licensed under a Creative Commons Attribution-NonCommercial 3.0 Unported License 
1

2

\title{
SUSTAINED CORPORATE CORRUPTION AND PROCESSES OF INSTITUTIONAL ASCRIPTION WITHIN PROFESSIONAL NETWORKS
}

\begin{abstract}
The last twenty years have seen some of the most dramatic cases of corporate corruption. One of the most striking features of these cases is the inability of professionals and professional firms to recognize and publicize corporate corruption. In this essay, we argue that professionals' failure to detect corporate corruption may be the result of institutional ascription that occurs within professional networks. Institutional ascription occurs as professionals ascribe probity and diligence to the behaviour of other professionals, and may contribute to sustain corporate corruption. Understanding the conditions and mechanisms that facilitate - or impede institutional ascription is thus important and we offer suggestions for how this line of research might be advanced.
\end{abstract}




\section{SUSTAINED CORPORATE CORRUPTION AND PROCESSES OF INSTITUTIONAL ASCRIPTION WITHIN PROFESSIONAL NETWORKS}

The last two decades have witnessed numerous and often dramatic cases of corporate fraud. Although several of the most sensational cases occurred in the United States, nevertheless corruption is a 'worldwide problem that cuts across ideological and cultural divides' (Zahra et al., 2005). The economic and social costs are substantial. In the United States alone, the estimated cost ranges from $\$ 200$ billion to $\$ 600$ billion per year (Schnatterly, 2003). In the United Kingdom, fraud in 2013 was estimated to be around f,52bn (The National Fraud Authority, 2013). And in Italy the 'hole' left by Parmalat alone was equivalent to $1 \%$ of the national GDP (Macintosh \& Quattrone, 2010). Further, indications suggest that the incidence of fraud is increasing (Coffee, 2005). At the end of 2011, 726 cases of corporate fraud were being pursued throughout the United States, several of which involved losses to investors in excess of $\$ 1$ billion (Federal Bureau of Investigation, 2010-2011). Perhaps more importantly, corporate fraud has shaken faith in financial markets. As The New York Times (2012) points out, 'capitalism cannot function without trust'. Yet, the National Opinion Research Council reported that in 2010 only $11 \%$ of respondents had confidence in banks and financial institutions.

Implicated in fraud and its outcomes are professional service firms. Even though these firms usually did not - although sometimes they did - wittingly and actively participate in fraud, they nevertheless failed to perceive and expose it. Analysts, audit and accounting firms, law firms, investment banks, and rating agencies, whose collective function is to ensure the probity of financial markets and to nurture the trust necessary for markets to function, were found seriously wanting. Santoro and Strauss (2013: 8-9), referring to the financial crisis of 2008, scathingly denounced 'the cavalcade of incompetence, corruption and recklessness' and pointed to 'the lawyers and accountants who saw, heard, and spoke no evil and who blithely papered over the whole fiasco'.

Not surprisingly, research on the role of professionals, and, in particular, of professional service firms, has attracted interest and gained momentum. Within this stream, important questions have been raised and significant insights obtained. In this essay, however, we propose that current research is dominated by a set of assumptions that restrict our attempts to understand the relationship between professional firms and the practice of corporate corruption. We argue that most accounts focus on a single professional, asking questions such as how and why they 
colluded in concealing fraud (e.g., Arnold \& de Lange, 2004; Braun, 2000; Cullinan, 2004); or, they focus upon a single profession and ask questions about the incentive and control mechanisms of the employing organization, and/or the effect of peer pressure, such as 'herding behavior' (e.g., Cote \& Goodstein 1999; Angle \& McCabe 2013), but networks are rarely the focus of inquiry (although, see Clark \& Newell, 2013). Most cases of corporate corruption, however, raise the role of such networks and it is with these networks that we are primarily concerned. For us, a critical yet neglected question is: Why did regulatory gatekeepers, collectively, fail to uncover and expose sustained corporate corruption?

In this essay, therefore, we do three things. First, we illustrate our focal interest by summarizing two highly publicized cases of corporate fraud practiced over a lengthy period - Enron and Parmalat. In doing so, we highlight and indicate the (deficient) role of gatekeeper networks. Second, we briefly review the literature on the relationship between professionals and their clients, noting the shift from an earlier assumption that the key risk is professionals taking advantage of their clients, to recognition of the risks of client capture and the loss of professional independence. We introduce the notion of 'institutional ascription' which has been shown to contribute to field-level regulatory failure (Gabbioneta et al., 2013) and review the argument that processes of institutional ascription dull the ability and motivation of gatekeepers to look for sustained corporate corruption. Third, we advance a research agenda and offer suggestions for how we might proceed. We identify where further research is needed in order to nuance and extend emerging theory, and, in so doing, inform policy.

Before turning to these themes, we acknowledge that our interest constitutes only part of the story. In some instances the ethical probity of professionals and professional service firms - e.g., Arthur Andersen in the Enron case and Grant Thornton in the Parmalat case - was clearly inadequate (Grey, 2003; Chabrak \& Daidj, 2007). We recognize that the gatekeepers may practice corruption, but this is not our interest here.

\section{SUSTAINED CORPORATE FRAUD: TWO EXAMPLES}

Our focus of interest can be illustrated by the examples of Enron and Parmalat. Partly this choice is because these cases are notorious and high profile. As Coffee (2005: 206) has said: 'Parmalat is the paradigmatic fraud for Europe (just as Enron and WorldCom are the representative frauds in the United States)'. In addition, these examples are dramatic in their scale and fraud was practised over several years: i.e., corruption was a sustained occurrence not a one-off irregularity. But they 
are not atypical (Dyck et al., 2013). On the contrary, the basic observations that we provide below also apply to numerous other, less dramatic cases.

Our particular interest, as noted above, is with the ring of 'gatekeepers' (Coffee, 2005: 2006; Gilson \& Krakman, 1984)*, which involves several clusters of actors, including several that profess to be self-regulating professions. Auditors examine a company's financial statements to ensure that they are 'accurate, truthful, and complete and prepared according to a set of [accepted] accounting standards', and to provide a written report that contains an opinion as to whether these financial statements are fairly stated and comply with the accounting standards (SEC, 2002). Securities analysts analyze a company's financial accounts, assess the company's future profitability, and offer advice to their clients (institutional investors) who are considering purchasing a company's shares. Analysts 'exercise independent professional judgment when conducting investment analysis, making investment recommendations, taking investment actions, and engaging in other professional activities' (CFA, 2013). Rating agencies assess a corporation's ability to pay back debt acquired through borrowing, make timely interest payments, and the likelihood of default. Investment banks assist corporations raise capital by underwriting and/or acting as the client's agent in the issuance of securities. As such, they conduct due diligence to ensure that their client's securities are worth purchasing. Finally, law firms assess the legality of commercial transactions, and advise corporations on their legal rights and duties. They provide legal advice on mergers and acquisitions, equity and bond issues, and disclosure requirements.

So, how well did these gatekeepers perform their roles in the Enron and Parmalat cases?

\section{Enron}

Enron Corporation was a U.S. energy company based in Houston, Texas. Prior to its bankruptcy in late 2001, it was one of the world's leading electricity, gas, pulp and paper, and communications companies, with claimed revenues of $\$ 101$ billion in 2000. The company achieved infamy at the end of 2001, when it was revealed that, for over a decade, its reported financial condition had been sustained by institutionalized, systematic, and creatively planned accounting fraud. The fraud was accomplished by putting debts and losses into 'offshore' entities that were not included in the company's financial statements; and, by the use of sophisticated and arcane financial transactions between Enron and related companies formed to remove

\footnotetext{
* The term 'gatekeepers' was, to our knowledge, first used by Gilson \& Kraakman (1984). It refers to field-level intermediaries who provide assurance to investors concerning information on corporate securities, equity offerings and similar data. The term is widely used by academics and regulators (e.g., the SEC).
} 
unprofitable entities from the company's books. The company collapsed on December 2, 2001, leaving behind $\$ 15$ billion in debt, worthless shares, and 20,000 workers who had lost their jobs.

The scope and length of Enron's fraud highlight the failure of financial market professionals to detect and report corporate corruption. Arthur Andersen (who audited Enron's financial statements) was accused of "helping Enron design accounting techniques or "models" that Enron could use to report income, cash flow and financial position more favourably than if the financial statements and related disclosures faithfully represented the economic substance of the transaction'; of having 'failed to exercise due care in auditing whether the third party entities used by Enron in its Prepay Transactions were SPEs ${ }^{\dagger}$ and whether the 3\% equity investments in the SPEs utilized by Enron in its FAS 140 Transactions were at risk'; and, of having failed to inform the company's audit committee about both the accounting policies in use at Enron and the unusual transactions the company had conducted (Batson Report, 2003: 40-41). As pointed out in the Batson report (2003: 39), 'Enron's financial statements and related disclosures were materially misleading. For example, virtually all of Enron's $\$ 979$ million of net income and $\$ 3$ billion of funds flow from operating activities for the year 2000, and approximately $\$ 8.6$ billion of fully recourse indebtedness not reflected on Enron's balance sheet as of December 31, 2000, were attributable to six accounting techniques used by Enron. Each of these accounting techniques was implemented with Andersen's assistance and approval. Each also was designed so that Enron could report the SPE transactions in a manner that was materially more favorable than their economic substance'. Arthur Andersen was also subsequently accused of obstruction of justice for shredding documents related to its audit of Enron, but was later acquitted by the Supreme Court. It settled for $\$ 72.5$ million in a class-action suit filed by Enron's investors, and agreed to pay $\$ 16$ million to Enron's creditors to settle claims of negligence.

In addition to Arthur Andersen, several highly prestigious banks and law firms were implicated. Nine financial institutions: J.P. Morgan Chase; Citigroup; Merrill Lynch; Credit Suisse First Boston; Canadian Imperial Bank of Commerce; Bank America; Barclays Bank; Deutsche Bank; and Lehman Brothers, were named as key players in a series of fraudulent transactions that ultimately cost shareholders more than $\$ 25$ billion. Each was accused of having helped Enron understate its debt and overstate its cash flow, by means of the deals they conducted. An email from J.P. Morgan Chase dated November 25, 1998, clarified how 'Enron loves these deals, as they are able to hide funded debt from their equity analysts because they (at the very least) book it as deferred [revenue] or (better yet) bury it in their trading liabilities' (CNN, 2002). According

† 'Special purpose entities' are legal entities created to fulfill specific, often temporary objectives, such as the financing of large projects or acquisitions of companies. 
to Robert Roach, Chief Investigator for the Senate Subcommittee, 'the evidence indicates that Enron would not have been able to engage in the extent of the accounting deceptions it did, involving billions of dollars, were it not for the active participation of major financial institutions willing to go along with and even expand upon Enron's activities'. Most banks, however, settled without admitting any wrongdoings.

Two law firms - Vinson \& Elkins and Kirkland \& Ellis - were added to the list of Enron defendants, accused of 'malpractice' because they failed to respond to red flags about Enron's accounting practices (Batson Report, 2003: 48). Vinson \& Elkins, in particular, gave Enron its approval to the accounting treatment the company 'sought for its transactions' (Batson Report, 2003: 48), thereby enabling it to report them at a much higher value than they warranted. Both law firms settled with the company and its shareholders without admitting guilt. In retrospect, Carrey (2003: 1) was prompted to ask: ' ... where were the lawyers?'

Financial analysts constitute a further group of gatekeepers who were criticized for not taking into account the company's cryptic 'mark to market' accounting, which allowed Enron to include as current earnings the profits they expected from future contracts, and for staying positive in their assessments and ratings well after the company's earnings had begun to plummet, when many of the contracts evaporated. As late as October 2001, up to the brink of its bankruptcy, all 15 analysts who produced analyses and recommendations on Enron's shares, rated Enron a 'buy', and 12 of them actually called it a 'strong buy'. Even as late as November 8, the date of Enron's disclosure that nearly five years of earnings would have to be recalculated, 11 of the 15 analysts recommended buying the stock. Only three analysts issued 'holds' and one a 'strong sell'. At the Enron hearings, Howard Schilit, an independent analyst, argued that 'for any analyst to say there were no warning signs in the public filings, they could not have been reading the same public filings as I did' (Forbes, 2002).

It was not until just four days before Enron declared bankruptcy that the three major credit rating agencies (i.e., Standard \& Poor's, Moody's, and Fitch) lowered their ratings of the company to below the mark of a safe investment. The Senate Governmental Affairs Committee noted how 'ratings have taken on great significance in the market, with investors trusting that a good credit rating reflects the results of a careful, unbiased and accurate assessment by the credit rating agencies of the rated company. But as with so many other market players, Enron caused this legendary reliability to be called into question', and that 'the credit rating agencies did not perform as expected...the agencies did not perform a thorough analysis of Enron's public filings; did not pay appropriate attention to allegations of financial fraud; and repeatedly took company 
officials at their word, without asking probing, specific questions - despite indications that the company had misled the rating agencies in the past' (Senate Governmental Affairs Committee. 2002: 97, 108).

\section{Parmalat}

Parmalat - a former food multinational based in Collecchio, a small town near Parma, in Italy practiced 'one of the largest and most brazen corporate financial frauds' (SEC, 2003) over a period of 13 years. The fraud started in 1990, when the company was listed on the Milan Stock Exchange, and ended in 2003, when the company defaulted on an expiring bond and had to file for bankruptcy protection. Manipulation of financial statements started immediately after the IPO, but the practice increased sharply in 1998 as the company experienced increasing difficulty in meeting market expectations. In 2002, Parmalat reported net earnings of $€ 252$ million, while in reality it had incurred a loss of $€ 918$ million. In the same year, Parmalat's reported book value was $€ 1,541$ million, while in fact there was a negative book value of around $€ 8.5$ billion. The final 'hole' left by the company amounted to $€ 14$ billion - almost twice the Group's 2002 annual sales turnover.

As in the Enron case, surprisingly few - if any - financial analysts had misgivings. In 2002, 21 of 29 analysts' reports issued on Parmalat suggested 'buying' the company's shares; seven suggested 'holding' them; and only one suggested that they should be sold. Even up to a few months before bankruptcy, over $85 \%$ of the reports issued by financial analysts were still suggesting that investors either 'buy' or 'hold' the company's shares. A few days before the fraud was detected, 57 out of 66 equity research reports recommended buying or holding the company's shares, whereas only eight contained a 'sell' recommendation. The Expert of the Public Prosecutor in the Parmalat case argued that analysts could have questioned the company's financial structure long before December 2002, when Merrill Lynch analysts for the first time pointed to the company's 'inefficient balance sheet management' (Merrill Lynch, 05-12-2002). Further, analysts have been accused of not developing an independent evaluation. As Dan Ackman, a Forbes journalist and lawyer, sarcastically noted 'the analysts say they reached their conclusions separately. But, even in a universe where two-thirds of the recommendations are "buy", the mathematical odds of a dozen analysts all reaching the same conclusion independently are less than one-in-100' (Forbes, 2002). 
In 2002, Standard \& Poor's, which had assigned Parmalat a BBB- rating since 2000, increased its outlook from stable to positive. The rating agency downgraded the company only in December 2003 when Parmalat was already on the verge of bankruptcy. The Public Prosecutor of the Parmalat case pointed out that even though the Group's balance sheets 'were abundantly false', rating agencies had shown no concern over 'the poor contribution to the Group EBITDA of the main operative company Parmalat SpA', and concluded that rating agencies would have raised concerns about the soundness of Parmalat's aggregated results had they identified that 'less than $15 \%$ of the Group's 2002 margins were accounted for by the parent company' whereas Bonlat allegedly accounted for a much higher percentage (Public Prosecutor, Parma).

Deloitte and Touche, which audited Parmalat's group accounts from 1999 to 2003, consistently issued unqualified audit opinions, indicating that the company's accounts were correct and reliable. Only at the end of October 2003, did Deloitte \& Touche issue a 'disclaimer' on the company's 2003 first-half financial accounts because the true value of its investment in Epicurum (whose value had previously been reviewed - and approved - by Grant Thornton) could not be determined. The Court of Milan scathingly noted that 'the fact that Deloitte didn't say anything about the company's 2002 financial statements is rather peculiar' (Sentence, Court of Milan: 187).

Grant Thornton, which audited Parmalat's financial accounts from 1990 to 1998 and the financial statements of several off-shore companies within the Group (including Bonlat, Parmalat's 'garbage can'), helped the company hide its debt and losses. One of Grant Thornton's partners later admitted:

'we went to talk to Tonna to find a way to hide the company's problems... from the new auditors. The solution devised was to create a new financial company located in the Cayman Islands - namely, Bonlat - in which they could hide the "problematic" entries. Grant Thornton was to audit this company, so that "no one would look into it" ... Bianchi said that he fully understood what was the initial role of Bonlat and that he anticipated - or, rather, preferred not to understand - the fictitious nature of many other operations that, year after year, passed through Bonlat' (Sentence, Court of Milan: 239).

Both Deloitte and Touche and Grant Thornton were heavily censured and fined.

Leading international banks - Morgan Stanley, Deutsche Bank, UBS, and Citigroup - and large Italian banks repeatedly worked with Parmalat and they, too, raised no concerns about its financial situation. They assisted the company in various bond issues, private placements, and 
mergers and acquisitions, and never once questioned the company or its management. According to Codacons, the Italian Consumer Association, banks 'sold investors "waste paper" that they had not checked' (Corriere della Sera, 2011). In addition, investment banks have been accused of not informing the public about the actual conditions of the companies in which they had invested, once these conditions had become clear to them, and, of having artificially inflated the company's shares, so as to give investors the impression of a healthy company (for a trenchant critique of the behaviour of investment banks, see Santoro \& Strauss, 2013).

Gian Paolo Zini, Parmalat's former lawyer, prepared the documents that Calisto Tanzi, the (then) CEO of Parmalat, had to sign in order to hide the company's fraud. In the hearings at the Court of Milan, Tanzi explained that he repeatedly did so at the request of Tonna, Parmalat's CFO, and Zini, and that he personally did not understand 'the technicalities used to fake the transactions'. He commented that Tonna and Zini had 'remarkable skills as fraudsters' (Sentence, Court of Milan: 89).

Financial journalists constantly praised the company, noting how Parmalat was one of the very few Italian companies to 'conquer the world' and that had the ability to 'represent Italy' (Il Sole 24 Ore, 25-02-1992). And although Consob (the Italian Securities and Exchange Commission) asked Parmalat to provide more information about its activity, the Commission was apparently satisfied with the answers provided by the company.

The evident conclusion is that in the Enron and Parmalat cases the network of gatekeepers did not perform their collective responsibility, which begs the following question: How can we explain the clear failure of the gatekeepers?

\section{THEORETICAL CONTEXT}

\section{Professionals and corporate corruption}

There has been a long-standing interest in the ethical dimension of professional behaviour and the role of the professional firm, an interest at the core of the debate over the place of professions in modern society. That debate pivots upon whether the privileges of professionalization, embedded in a state sanctioned monopoly of supply and the right of selfregulation, are necessary because of the social functions that they serve (e.g., Friedson, 1994), and/or whether they are vehicles of stratification and abuse (e.g., Johnson, 1972; MacDonald, 1995). 
A different and less overtly political way of approaching the dilemma uses the language of institutional theory. Professional firms are conceptualized as embodying two 'logics'. First, a 'trusteeship logic' (Brint, 1994) in which professionals temper the pursuit of personal (usually economic) gain, in order to further the interests of their clients within a framework of regulations; and, second, a market or commercial logic, which involves harnessing and marketing expertise to those able to pay for it. Professional firms, according to this language, are 'hybrid' organizations (Pache \& Santos, 2010: 2013; Battilana \& Dorado, 2010; Greenwood et al., 2011) in which two logics are concurrently pursued. They are, thus, inevitably conflicted sites in which professionals experience 'institutional tension' as they seek to retain an appropriate balance between the imperatives and demands of the two logics (Lander et al., 2013: 130; see also, Muzio et al., 2013). The imagery is of a struggle to appropriately accommodate disparate sets of institutional prescriptions.

Critics have long pointed to the asymmetry of knowledge in the relationship between professional and client and recognized the risk that professional firms might temper their commitment to the trusteeship logic, and pursue their self-interest (Robinson, 1978; Knapp, 1985; Sharma, 1997; Louwers, 1998). For the most part, however, until the 1960s it was largely assumed that professionals would not engage in professional misbehaviour because of the lattice of normative controls that ensure an appropriate balance between the trusteeship and commercial logics (Zeff, 2003(a): 2003(b)).

Sharma (1997) summarizes this optimistic position by identifying four controls that, it was believed, would underpin the trusteeship logic and ensure professional behaviour. First, he suggests that if a professional and client interact regularly, opportunistic behaviour is less likely to occur because increasing trust ...generates the expectation that one will not undermine the other's interests even in the face of countervailing short term opportunities'. A second control is the profession itself, which monitors and regulates members. Employing organizations make up a third control, in that peers within professional service firms are assumed to press and enforce normative compliance; and, in any case, the potential risk to a firm's reputation should professional misconduct occur will make an organization vigilant. Finally, Sharma suggests that clients can be an effective check upon misconduct to the extent that they have in-house expertise able to deal effectively with outside experts. Implicit in this analysis is that the problem is how to control the professional, not the client, and the optimistic conclusion is that it is achieved.

The position of clients, of course, can be affected by how they are organized. Merton (1957) and Rex (1970), for example, observed that large clients can provide a strong legitimate influence for 
a profession, lending credibility to its activities and helping establish its claims of value. But these studies ignored the possibility that clients might subvert professional conduct. In the 1980 s and 1990s, however, the potentially adverse influence of clients was increasingly recognized. Knapp (1985), for example, observed that clients with better financial records are more able to influence their advisors. Similarly, Louwers (1998) pointed to a client's size and the length of the professional relationship as factors that strengthen the position of the client. Hackenbrack and Nelson (1996) noted that the client's influence is higher when the level of engagement risk is low and Lord (1992) suggested that clients are less dominated when professionals are subject to market competition. Overall, these studies questioned the earlier assumption of highly dependent and thus vulnerable clients by pointing to factors that strengthen the position of the client. Nevertheless, the recurrent tone of these studies was that clients are only relatively less dependent upon their advisors, highlighting the importance of Sharma's four sets of controls.

Events of recent years have qualified and undermined the optimistic stance of previous decades. Moore et al. (2006: 12) believe that 'auditor independence has remained and elusive promise...' Sikka (2009: 430), also referring to accounting firms, puts it more bluntly:

'There is evidence that major firms have participated in price fixing, fraud, bribery, corruption, money laundering, falsification of clients financial statements, audit reports and, despite repeated warnings and fines, have ignored rules on auditor independence'.

Similarly, policy makers are today clearly less sanguine about the motivation or capability of the professions and of professional service firms to appropriately balance the trusteeship and commercial logics. The Sarbanes-Oxley reform directly signals that professional self-regulation is, at best incomplete and, at worst, a myth. Moreover, the professions themselves are concerned. Suddaby, Gendron and Lam (2009: 409) note that 'the dubious relationship between Arthur Andersen and Enron, as well as the apparent inability of even elite members of the profession to self-regulate,... have initiated an era of critical self-appraisal among accountants'.

Admittedly, not all studies are pessimistic. Lander et al. (2013: 144) conclude that 'the sun is not setting on professionalism in mid-tier accounting firms' (for contrary examples in the UK, however, see Sikka, 2009: 430-431). Similarly, Suddaby, Gendron and Lam (2009: 424) concluded that attitudes about professional commitment remain high. Nevertheless, the dominant position of recent years sees the relationship between professionals and their clients less as one that advantages the professional than as one characterized by 'client capture'. The notion of the 
'independent' professional, for many observers, is a sham (Leicht \& Fennel, 2001). Client capture implies that professionals lose their independence (see Hanlon, 1994; Bazerman et al., 1997; Bazerman \& Moore, 2011; Wilmott \& Sikka, 1997). For example, contrary to the earlier view that a professional firm would diligently work to protect its reputation by nurturing the trusteeship logic, Macy and Sale (2003: 1168) propose that incentive structures within accounting firms make it virtually impossible for individual auditors to be independent of significant clients because the professional's success depends on the quality of the relationship they form with the top managers of the client they are auditing'. Similarly, Klimentchenko (2009) and Sikka (2009) underline that audit firms have become reluctant to challenge their clients for fear of losing the audit and any add-on assignments.

The lengthy debate over the appropriateness of multi-disciplinary partnerships (e.g., Suddaby \& Greenwood, 2001; Greenwood et al., 2002; Suddaby \& Greenwood, 2005) speaks to this same concern. Critics have highlighted how accounting firms that offer consultancy services may use the audit function 'as a springboard to more lucrative consulting services' and provide only cursory audit (Levitt, 2000; see also, Coffee, 2006). Further, firms that offer both audit and consultancy services impair investor confidence in auditor independence and lead to declining confidence in public capital markets' (SEC, 2000). To date, however, there is no conclusive evidence that providing both audit and consultancy services reduces audit quality (e.g., Frankel et al., 2002; Ashbaugh et al., 2003; Kinney et al., 2004; Knechel \& Sharma, 2012).

Nevertheless, Wyatt $(2004)^{\ddagger}$ points to the expansion of accounting firms into the provision of consultancy services as one cause of the decline of professional standards and the erosion of auditor independence. He illustrates this thesis by tracing the evolution and subsequent demise of Arthur Andersen over a period of 40 years, concluding that the hiring of non-accountants introduced (in the terms of Pache \& Santos, 2010) 'representatives' of the commercial logic, thus adversely shifting the 'internal culture':

'It wasn't that consulting personnel was unprofessional in performing their work, it was that their actions and behaviour were far more commercially driven than would be acceptable for audit personnel. The consultants did not focus on investor or creditor interests, and their attitudes gradually affected how auditors approached their work' (Wyatt, 2004: 50).

‡For a similar but more detailed account that reaches similar conclusions, see Zeff, 2003(a): 2003(b). 
In our terms, Wyatt's argument is that the balance between the trusteeship and commercial logics tilted in favour of the latter; and 'undermined the core values of the professional firm' (Wyatt, 2004: 50). Much of this thesis, of course, is well-known. But an important sub-theme in the Wyatt story is worth highlighting. He connects the organization of professional work within professional service firms and the decline of audit standards to wider social processes:

'Client share prices were rising in the booming stock market, executives were becoming wealthy (on paper at least), and accounting partners felt entitled to participate in the economic boom by achieving increasing earnings in their firms... In retrospect, it is easy to see the greed factor at work' (Wyatt, 2004: 49).

Turning to the behaviour of analysts, a similar story can be told. Research has provided convincing evidence of the conflicts of interests that arise when investment banks provide both investment and rating services. Dugar and Nathan (1995) and Hayward and Boeker (1998) show that financial analysts within brokerage firms that also provide investment banking services are more optimistic in their earnings forecasts and investment recommendations relative to other analysts (although see Cowen et al., 2006 for opposite results). Lin and McNichols (1998) found that the growth forecasts and recommendations of lead and co-underwriter analysts were significantly more favorable than those made by unaffiliated analysts. Michaely and Womack (1999 - see also O’Brien et al., 2005 and Barber et al., 2007) observed how stocks that underwriter analysts recommend performed more poorly than the 'buy' recommendations of unaffiliated brokers prior to, at the time of, and subsequent to the recommendation date and concluded that the recommendations by underwriter analysts show significant evidence of bias.

Even independent analysts, however, may succumb to a firm's pressures in order to maintain useful relationships with senior management (Ke \& Yu, 2006; Westphal \& Clement, 2008). Analysts may be tempted to issue overly optimistic earnings forecasts in order to please the corporation's management (e.g., Francis \& Philbrick, 1993; Das et al., 1998; Lim, 2001; Matsumoto, 2002; Richardson et al., 2004).

The shift towards a more pessimistic portrayal of the independence and professionalism of professional service firms has directed increasing attention to understanding the context and influences upon professional behaviour. And, despite many insights (for reviews, see Jain, 2001; Palmer, 2012; Greve et al., 2010), we clearly have much more to learn about professional behaviour and its relationship to corporate corruption. Here, however, we wish to push for 
further research into the interaction between different types of professional firms ${ }^{\S}$ (rather than into the dyadic relations between a professional firm and its client); and suggest a particular mechanisms - 'institutional ascription' (Gabbioneta et al., 2013) - that we believe deserves special attention, partly because it has been widely neglected; and, perhaps more importantly, because it may be an especially important collective mechanism.

\section{Institutional ascription}

Gabbioneta et al. (2013) emphasize that a limiting assumption of much previous work is the emphasis given to dyadic relationships - such as the relationship between an auditor and a client, or an analyst and a client. This assumption underplays the level of embeddedness that develops from the repeated and prolonged interactions between clients and their multiple advisors; and, it ignores the frequent close relationship between those advisors. Yet, as we highlighted earlier, many (perhaps most) cases of corporate corruption involve - although in different permutations - a multiplicity of interacting professional firms. Accounting, law, consultancy, investment firms and rating agencies are often implicated at the same time. Thus, as noted by Palmer (2012: 36), 'most wrongful courses of action require at least the tacit cooperation of others and thus are at least nominally collective'. Hence, we need to give greater attention to the network of gatekeepers. And it is in this context that Gabbioneta et al. introduce the idea of institutional ascription.

Institutional ascription within professional networks occurs when professionals assume that other professionals are behaving 'professionally'- that is, when professionals assume that other professionals have conducted and completed their work honestly and diligently, and consistent with the idealized version of professional behaviour. This assumption, in turn, makes them accept uncritically the work done by other professionals. It mitigates the perceived need for more probing critical inquiry and removes any semblance of a second opinion; or, as academics would put it, of triangulation of evidence and analyses. Professionals assume that the opinions expressed by other professionals are reliable and robust, and - importantly - base their own work also on these opinions. Ascription is consistent with the 'moral seduction' thesis put forward by Moore et al. (2006) who emphasize that, contrary to popular imagery, corruption is often not an

\footnotetext{
$\S$ Not all studies are exclusive dyadic in their focus. There has been an interest in mimetic behavior amongst investment analysts (e.g., Welch, 2000). But these studies do not open out to the network of gatekeepers. However, these studies confirm that analysts do not conduct rigorous independent analyses. Welch concludes: 'I am inclined to interpret this evidence as supportive of theories in which analysts follow the consensus, based on little or no information' (2000: 386; emphasis added).
} 
occurrence of a personal decision to deviant from an ethical code, but the outcome of systemic structural features that shape professional behaviour.

The assumption that others are acting professionally means that, if any link in a professional network is weak, the entire network is at risk of 'contagion' and thus vulnerable to collective blindness. The initial weakness propagates inside the network as more and more professionals rely on the work of other professionals to reach their own - supposedly independent assessment of the firm. The initial involvement of a few actors results in the entire network being implicated in the failure to expose corporate corruption. As a consequence, networks of professionals, which are supposed to act as gatekeepers against corporate corruption, may actually - albeit unwittingly - enable its concealment because of reciprocal and socially emphasized processes of collective ascription.

In the two cases summarized above, we see several instances of ascription.

Primary auditors assumed that secondary auditors had behaved 'professionally', that is to say, that they diligently examined the accounts of the companies within the group. Until 2002, Deloitte and Touche based its 'unconditional opinion' on the group's accounts also on the work of Grant Thornton, which at that time audited a number of Parmalat's subsidiaries, including Bonlat, the group's 'garbage can' (Sentence, Court of Milan: 54). Auditors from Deloitte and Touche stated clearly: 'our opinion, contained in this report, as far as the values of these subsidiaries reported in the consolidated accounts, relies also on the work of these auditors' (Parmalat Annual Report, 2000). Only in 2002, did Deloitte and Touche decide to check Bonlat's accounts: finding themselves unable to determine the amount of money invested by the company in the Epicurum fund, the auditors for the first time issued a 'conditional opinion' on the group's accounts (Sentence, Court of Milan). As The Economist (2004) put it, 'Deloitte seems to have accepted Grant Thornton's audits unquestioningly, while bankers and investors took the audited group figures as reassurance that, although complex, the group's finances were essentially sound'. And, according to the Court of Milan, 'The crime of false audit committed by the principal auditor Deloitte and Touche is an inevitable consequence of the crime referred to in Chapter D [false audit by Grant Thornton]: when Penca and Bianchi provided false data to the principal auditor, they knew that the latter would also provide a false certification' (Sentence, Court of Milan: 244).

Credit rating agencies, subsequently, based their ratings on the data contained in financial statements that they assumed has been 'properly' checked. What they did not do, was conduct 
their own detailed and systematic independent analysis. The Committee that investigated the role of the rating agencies in the Enron case was very clear in this respect:

'the agencies did not perform a thorough analysis of Enron's public filings; did not pay appropriate attention to allegations of financial fraud; and repeatedly took company officials at their word, without asking probing, specific questions - despite indications that the company had misled the rating agencies in the past' (Senate Governmental Affairs Committee, 2002: 108).

Former SEC Chief Accountant Lynn Turner testified that his own initial review of Enron's financial statements raised more questions than they answered and that anyone doing a similar review should have noted their opacity. At the hearings, however, when Chairman Lieberman asked analysts whether in retrospect, they felt they should have asked more questions of Enron, Ronald Barone of Standard and Poor's responded, 'Senator, we rely on the audited financial statements .... We are not forensic accountants, if that is the question, and we don't have subpoena power. . . . To To which, Mr. Pellecchia, a Fitch analyst, added: ‘... A company's public certified financial statements are the bedrock of any analysis of the value or the prospects of a company's stock'. Concerns about excessive reliance upon the work of auditors were raised also in the Parmalat case, when the Public Prosecutor highlighted how rating analysts 'did not develop a true analysis of the company's financial statements', which would have shown that these statements 'were abundantly false' (Public Prosecutor, Parma).

Audit firms, in turn, relied also on the work done by law firms. When asked if she 'thought that because Vincent \& Elkins had said there was no problem, ...that did not trigger any kind of requirement...', Nancy Temple, in-house attorney for Arthur Andersen, answered that she 'noted that the law firm reported that there was nothing further to follow up on at that point in time; and this was a very large law firm representing Enron Corporation'. Similarly, in the Parmalat hearings, Marco Verde - one of the auditors working for Parmalat - testified that 'during the meeting, Del Soldato tried to convince him that they had correctly valued the transaction and, then, asked Gian Paolo Zini...to tell them his opinion. Zini confirmed Del Soldato's version and promised that, in a few days, he would send a memo.... The memo in question didn't arrive in time... as soon as he [Mr. Verde] received the document, he...talked about it with Bianchi, who said that "if a lawyers who...is an expert in these matters says such a thing, at least we have a memo that justifies us". Verde also pointed out that even Penca agreed on accepting Zini's version' (Sentence, Court of Milan: 76). 
Likewise, securities analysts formulated their investment recommendations using financial data they thought had been diligently audited, and also relied on the credit ratings provided by the rating agencies. As one analyst told The New York Times (2001): 'he persisted in recommending the stock' because he didn't 'think accountants and auditors would have allowed total shenanigans'. In some cases, analysts clearly stated in their equity reports their reliance on the work of auditors and/or rating agencies. Analysts at Cheuvreux, for example, noted that

'S\&P reiterated its positive outlook on Parmalat. The positive outlook reflects that Parmalat's ratings could be upgraded by one notch in the medium term, if the expected improvement in the group's credit measures materializes and the macroeconomic and currency environment in LatAm stabilizes' (Cheuvreux, 2003).

Similarly, Curt Launer of Credit Suisse First Boston wrote that

'the so-called LJM Partnerships were fully disclosed in Enron's financial statements and were subject to appropriate scrutiny by Enron's board, outside auditors and outside legal counsel. Considering the disclosures made and the appropriateness of the accounting treatment... we anticipate that the negative sentiment surrounding these issues will dissipate over time' (CSFB, 2001; emphasis added).

At the Enron hearings, Charles Prince from Citibank said that he

'never anticipated that a financial intermediary like Citigroup would be criticized for the accuracy of the accounting treatment that a Fortune 10 company gave to its transactions with the express approval of a then-highly respected Big Five accounting firm'

and that

'at the time we entered into these transactions, we never imagined that Arthur Andersen wouldn't even exist a year later or that a failure of ethics would have destroyed Enron, a company ranked in the top 20 on the list of most admired companies in the year 2001'.

He also admitted that

'.... in hindsight, our people were too comfortable with what was told to us by the outside auditors, the law firms that structured and closed these transactions, and 
Enron themselves. I think that at that time we did not view ourselves as being responsible for what Enron did with its own books'.

Similarly, Rick Caplan, a senior professional from Citigroup, noted how in December 2000, when the Fishtail transaction was agreed to, the firm had no reason to believe that any such determinations were not being made by Enron and/or Arthur Andersen, which was then one of the Nation's premier accounting firms, in accordance with Generally Accepted Accounting Principles'.

In other cases, analysts mindlessly reproduced a customary practice in financial markets. As one of our informants candidly admitted,

'we actually do something similar to an act of faith... if we know that those who have more information than we do have already expressed a positive opinion, to same extent we raise our hands... and consider the financial situation as given... we do not question... [issues] on which rating agencies have already given their opinion...' (interview; emphasis added).

Investment banks also assumed that inspectors at Consob (the Italian equivalent of the U.S. SEC) had done their work diligently. Yet, it had failed to do so, as was caustically noted by the Judge of the Court of Milan, who partially 'absolved' the Bank of America: 'Why should Bank of America protest when Consob performs an inspection activity - with much wider powers... at the end of which no irregularities are found and the accounting figures provided are approved, and Consob invites the Group to keep that meritorious and comprehensive level of disclosure and transparency in the future?' (Sentence, Court of Milano: 325).

In sum, in both the Enron and Parmalat cases, the professionals involved ascribed probity and rigor to the work of other professionals and, by doing that, felt less need to dig deeply in performing their own, supposedly independent analyses. There was a ring of reliance and unquestioning ascription of trust to others' professionalism. In consequence, there was a triangulation of complacency. The paradox, in other words, is that professionals trusted other professionals whilst being 'unprofessional' themselves. This paradox indicates that a central challenge confronting professions and professional firms is not simply guarding against the risk of the commercial logic dominating the trusteeship logic (although that risk is highly significant) but also of ensuring that the practices and behaviors of the trusteeship logic are actually implemented even in the absence of commercial pressures. In institutional terms, professional 
behaviours associated with the trusteeship logic cannot be assumed to be self-reinforcing; they require institutional maintenance (Lawrence et al., 2009).

\begin{abstract}
A RESEARCH AGENDA
We have advocated the need to understand the network of professionals that circle corporations and the role that this network plays in uncovering and/or concealing processes and practices of corporate corruption. In particular, we have elaborated the neglected mechanism of institutional ascription. We conclude by proposing lines of future inquiry.

First, research should go beyond the traditional focus upon the dyadic relationship between firms and their clients. We need to investigate the relationships between professional firms, and probe their nature, the mechanisms of reproduction, and their consequences. In particular, it is important to explore whether repeated involvement of the same firms over time increases the incidence of neglected fraud. As we noted earlier, the idea that audit firms may be 'captured' by their clients and constrain the application of the trusteeship logic is a recurrent, pervasive theme in the accounting literature. What is missing from this literature, however, is an analysis of whether prolonged relations between a corporation and other professional firms may wittingly or unwittingly lead to 'unprofessional' behaviour.
\end{abstract}

In this respect, we also need to learn more about whether some relationships between professional firms are particularly at risk of 'missing' corruption, and about why that may be the case. There are, as we have already noted, studies that focus on the possible conflicts of interest that arise when a firm provides audit and consultancy services, or when a bank acts as investment bank and as broker. These studies, however, neglect the possibility that conflicts of interests may arise between professional service firms. For example, one may question how 'independent' is a broker who has repeated and frequent relationships with the same investment bank; or, how 'independent' consultants are from auditors that may 'suggest their name' to potential clients. If supposedly independent professional firms are actually dependent and/or overly reliant upon each other, then the question is raised whether this 'dependence' may be problematic.

Enquiries of this sort would provide opportunities to explore the key conduits through which networks and relationships are cemented and reinforced. For example, client personnel can be a key conduit for the maintenance and reinforcement of professional networks. In the case of Enron, the firm's head of legal services previously worked for Vinson \& Elkins, their external 
legal advisor. A Vinson \& Elkins partner, in charge of the Enron account, used to be an Enron employee. Many of Enron's in-house accountants were ex Arthur Andersen employees. In this case the conduits for creating the network of professionals came through the client. Another conduit of professional networks could be the movement of human capital that happens between large multidisciplinary professional service firms, because of status and reputational equivalence. It is likely that such movement forms the basis of initiating networks that may be susceptible to ascription.

The movement of human capital across professional service firms is also related to the pressures of size and diversification that these firms experience. Increasing sophistication of in-house counsel and accounting departments, combined with pressures of finding and maintaining a growing roster of clients in a recessed economy, is prompting professional service firms to provide unique, highly specialized services. For global professional service firms this pressure to specialize involves diversification through horizontal acquisitions. An implication for their clients is a narrower range of options when selecting professional advisors. Ernst \& Young, for example, are the professional firm of choice for technology firms because of the firm's acquired expertise in areas of intellectual property rights as well as in technology and digital growth. It is interesting to note that large Internet companies such as Google, Twitter, Square and Amazon all have Ernst \& Young as their external auditor. Google, Twitter and Square also happen to share the same external legal counsel. This commonality does not imply that there is, or will be, professional misbehaviour, but it does illustrate the intertwined relationships that connect professional service firms by virtue of their having a common set of influential clients and that thus increase the risk factor of ascription.

Another condition that may influence the incidence of ascription is the length and frequency of the relationships between professional service firms. Frequent, long-lasting relationships may reduce the perceived likelihood of opportunistic behaviour and this, in turn, may facilitate ascription of diligence and competence to the other firm. A third condition that may foster institutional ascription is geographical proximity, which enables frequency of interaction and the development of shared norms of understanding. Professionals that meet face-to-face and who socialize together may be more likely to ascribe professionalism to each other than are professionals that do not know each other. On the other hand, it could be argued that impersonal relations might be more conducive to ascription. Face-to-face interaction may work to dispel the myth of profession. 
In raising the importance of institutional ascription we have drawn heavily on two cases that, though they clearly implicate several professional firms, heavily emphasise the role of accounting firms and financial analysts. It would be interesting to probe whether firms in a particular profession are more likely to be the recipient of ascriptive processes; i.e., whether there is a status ranking of professions such that outsiders are less likely to question the views and opinions of its members. The pronouncements of higher status professions, we suspect, (e.g., law) are less likely to be questioned than those of less mature or 'quasi' professions (such as management consultancy).

Professions are distinguished not only by their relative status. On the contrary, they vary in the strength of their regulatory practices and their ability to oversee their members' behaviour (von Nordenflycht, 2010; Greenwood et al., 2011). It follows, therefore, that some professions may be more vulnerable than others to failure of regulatory oversight. To the extent that such oversight is weak, the probability of institutional ascription is enhanced. That is, institutional ascription will occur more readily in professions where self-regulation is weak. Professions themselves, of course, are not homogeneous and some member firms, perhaps especially those whose boundaries outstrip those of professional regulators, may be less policed (Greenwood \& Suddaby, 2006; for a fuller discussion of this issue, see Faulconbridge \& Muzio, 2011). Yet, it is the largest firms that typically receive greater media attention, which might motivate them to more careful compliance with, and maintenance of, the trusteeship logic. The interstices of selfregulation are thus intriguingly multifaceted and complex and comprise promising avenues of inquiry. We need to explore and pinpoint the sources and mechanisms of ascription and the subset of firms and professions that they implicate.

The failure of gatekeepers has lead to regulatory initiatives but there are signs that these may be being watered down. In the US, the Sarbanes-Oxley Act and the Dodd-Frank Wall Street Reform and Consumer Protection Act were designed to increase accountability of the professions (especially accountants and financial analysts) and re-establish trust in the financial market. The Sarbanes-Oxley Act removed self-regulation from the accounting profession by creating the Public Company Accounting Oversight Board (PCAOB). The Act also imposed significant risk compliance requirements for publically traded firms and the compulsory rotation of auditors. An unintended consequence was that most of the business related to risk compliance accrued to the large professional service firms. Almost a decade after the Sarbanes-Oxley Act was passed, in July 2013 the House of Representatives approved a bill that prohibits the PCAOB from forcing public companies to automatically change or rotate their auditors. Soon after, the United 
Kingdom moved away from mandatory auditor rotation in favour of 'audit tendering' every ten years. Similarly, the European Union, in October 2013, agreed to let banks and 'systemically important' companies retain the same auditor for fifteen years and for other public interest entities to do so for twenty years. So the way we see it, the regulatory constraints that may have had an impact on the working of professional networks have been debilitated and recent compliance requirements have given additional leverage to large professional service firms. How these and any further changes affect the incidence of institutional ascription is an intriguing question and one that should be monitored. Perhaps more worryingly, the watering down of regulatory changes confirms the pessimistic thesis of Tetlock et al (2006:12) that issue cycles in the political world' deflect demands for accountability.

In much the same way that not all professionals, professional firms and professions are the same, neither are clients. Although our emphasis is upon relationships between members of the regulatory network, the incidence of institutional ascription will be affected by characteristics of the client. Parmalat was a 'celebrity' firm (e.g., Rindova et al., 2006; Ahmadjian \& Robinson, 2001) which affected how it was viewed and treated by analysts and rating agencies. Other firmlevel characteristics that might be important include the client's history and performance, its formal governance arrangements, and its reputation. A fuller understanding of ascription, therefore, should include analysis of how these and other client characteristics moderate or amplify the attitude of gatekeepers, and the circumstances under which they do or do not do so.

Finally, our two cases - Enron and Parmalat - raise the importance of time. We have emphasized that most studies of corruption ignore the duration and focus instead upon its occurrence. For us, it would be interesting to explore whether longer durations of corruption are signally associated with higher levels of institutional ascription. That is, does the possibility of sustained corruption increase if the relationships between gatekeepers are of long standing and characterised by institutional ascription? Isolating and comparing the involvement of institutional ascription in shorter and longer periods of corruption might be an informative line of inquiry.

A different aspect of time concerns the era of occurrence. Almost all studies of the financial implosion of the last decade point out that it followed a lengthy period of economic growth. Are such eras more likely to encourage institutional ascription? The temporal context, in this sense, matters. Similarly, it seems reasonable to suppose that the aftermath of highly publicized market failures, such as Enron and Parmalat, would sweep away at least some measure of complacent ascription. Financial crises ebb and flow (Kindleberger \& Aliber, 2005): so, too, we suspect, does the incidence of institutional ascription. 
1

2

3

4

5

6

7

8

9

10

11

12

13

14

15

16

17

18

19

20

21

22

23

24

25

26

27

28

29

30

31

32

33

34

35

36

37

38

39

40

41

42

43

44

45

46

47

48

49

50

51

52

53

54

55

56

57

58

59

60

These suggestions for future research are premised on the importance of understanding the network of relationships between professional firms, and in particular the mechanism of institutional ascription, which undermines the trusteeship logic. Declining trust in the ability of professional gatekeepers to properly and effectively discharge their roles as gatekeepers and watchdogs or market arrangements is a fundamental problem. It is time to respond. 


\section{REFERENCES}

Ahmadjian, C.L., Robinson, P. 2001. Safety in Numbers: Downsizing and the Deinstitutionalization of Permanent Employment in Japan. Administrative Science Quarterly, 46 (4): 622-654.

Angel, J.J., McCabe, D. 2013. Ethical Standards for Stockbrokers: Fiduciary or Suitability? Journal of Business Ethics, 115 (1): 183-193.

Arnold, B., de Lange, P. 2004. Enron: An Examination of Agency Problems. Critical Perspectives on Accounting, 15 (6-7): 751-765.

Ashbaugh, H., LaFond, R., Mayhew, B.W. 2003. Do Nonaudit Services Compromise Auditor Independence? Further Evidence. The Accounting Review, 78 (3): 611-639.

Barber, B.M., Lehavy, R., Trueman, B. 2007. Comparing the Stock Recommendation Performance of Investment Banks and Independent Research Firms. Journal of Financial Economics, 85 (2): 490-517.

Batson Report. 2003. Final Report of Neal Batson, Court-Appointed Examiner. Chapter 11, Case No. 01-16034 (AJG). Jointly Administered.

Battilana, J., Dorado, S. 2010. Building Sustainable Hybrid Organizations: The Case of Commercial Microfinance Organizations. Academy of Management Journal, 53 (6): 14191440.

Bazerman, M.H., Morgan, K.P., Loewenstein, G.F. 1997. The Impossibility of Auditor Independence. Sloan Management Review, 38 (4): 89-94.

Bazerman, M.H., Moore, D. 2011. Is it Time for Auditor Independence yet? Accounting, Organizations and Society, 36 (4-5): 310-312.

Braun, 2000. The Effect of Time Pressure on Auditor Attention to Qualitative Aspects of Misstatements Indicative of Potential Fraudulent Financial Reporting. Accounting, Organizations and Society, 25 (3): 243-259.

Brint, 1994. In an Age of Experts: The Changing Role of Professionals in Politics and Public Life. Princeton, NJ: Princeton University Press. 
Carrey, B.S. 2003. Symposium on Enron, WorldCom, and their Aftermath: Enron - Where were the Lawyers? Vermont Law Review, 871.

CFA, 2013. Code of Ethics and Standards of Professional Conduct.

Chabrak, N., Daidj, N. 2007. Enron: Widespread Myopia. Critical Perspectives on Accounting, 18 (5): $539-557$.

Cheuvreux, 2003. An Expensive Mistake, 06/03/2003.

Clark, C.E., Newell, S. 2103. Institutional Work and Complicit Decoupling across the US Capital Markets: The Role of Rating Agencies. Business Etbics Quarterly, 23 (1): 1-30.

CNN, 2002. Congress: Banks helped Enron. 23/07/2002

Coffee, J.C. 2005. A Theory of Corporate Scandals: Why the USA and Europe Differ. Oxford Review of Economic Policy, 21 (2): 198-211.

Coffee, J.C. 2006. Gatekeepers: The Professions and Corporate Governance. Oxford, UK: Oxford University Press.

Corriere della Sera, 2011. Processo Parmalat, assolte le banche. La procura: «Indagini doverose». 18/04/2011.

Cote, J., Goodstein, J. 1999. A Breed Apart? Security Analysts and Herding Behavior. Journal of Business Ethics, 18 (3): 305-314.

Cowen, A., Groysberg, B., Healy, P. 2006. Which Types of Analyst Firms Are More Optimistic? Journal of Accounting and Economics, 41 (1-2): 119-146.

CSFB, 2001. Credit Suisse First Boston Research Report on Enron Corp., 19/10/2001.

Cullinan, C. 2004. Enron as a Symptom of Audit Process Breakdown: Can the Sarbanes-Oxley Act Cure the Disease? Critical Perspectives on Accounting, 15 (6-7): 853-864.

Das, S., Levine, C.B., Sivaramakrishnan, K. 1998. Earnings Predictability and Bias in Analysts' Earnings Forecasts. Accounting Review, 73 (2): 277-294. 
Dugar, A, Nathan, S. 1995. The Effect of Investment Banking Relationships on Financial Analysts' Earnings Forecasts and Investment Recommendations. Contemporary Accounting Research, 12 (1): 131-160.

Dyck, I.J.A., Morse, A., Zingales, L. 2013. How Pervasive is Corporate Fraud? Rotman School of Management Working Paper No. 2222608.

Economist, The. 2004. Europe's corporate governance. Parma splat. What are the lessons from the scandal at Europe's largest dairy-products group? 15/01/2004.

Faulconbridge, J.R., Muzio, D. 2012. The Rescaling of the Professions: Towards a Transnational Sociology of the Professions. International Sociology, 27 (1): 136-152.

Federal Bureau of Investigation. 2010-2011. Financial Crimes Report to the Public. Fiscal Years 20102011 (October 1, 2009 - September 30, 2011).

Forbes, 2002. Congressional Hearings. Enron Analysts: We Was Duped, 27/02/2002.

Frankel, R.; Johnson, M., Nelson, K. 2002. The Relation Between Auditors' Fees for NonAudit Services and Earnings Management. The Accounting Review, 77 (Supplement): 71-105.

Francis, J., Philbrick, D. 1993. Analysts' Decisions as Products of a Multi-Task Environment. Journal of Accounting Research, 31 (2): 216-230.

Friedson, E. 1994. Professionalism Reborn: Theory, Prophecy, and Policy. Chicago, IL: Chicago University Press.

Gabbioneta, C., Greenwood, R., Mazzola, P., Minoja, M. 2013. The Influence of the Institutional Context on Corporate Illegality. Accounting, Organizations and Society, forthcoming.

Gilson, R., Kraakman, R. 1984. The Mechanisms of Market Efficiency. Virginia Law Review, 549: 612-621.

Greenwood, R., Suddaby, R., Hinings, C.R. 2002. Theorizing Change: The Role of Professional Associations in the Transformation of Institutionalized Fields. Academy of Management Joumal, 45 (1): 45-57.

Greenwood, R., Suddaby, R. 2006. Institutional Entrepreneurship In Mature Fields: The Big Five Accounting Firms. Academy of Management Joumal, 49 (1): 27-48. 
Greenwood, R., Rynard, M., Kodeih, F., Micelotta, E., Lounsbury, M. 2011. Institutional Complexity and Organizational Responses. The Academy of Management Annals, 5 (1): $317-$ 371.

Greve, H.R., Palmer, D., Pozner, J.E. 2010. Organizations Gone Wild: The Causes, Processes, and Consequences of Organizational Misconduct. Academy of Management Annals, 4 (1): 53107.

Grey, C. 2003. The Real World of Enron's Auditors. Organization, 10 (3): 572-576.

Hackenbrack, K., Nelson, M.W. 1996. Auditors' Incentives and Their Application of Financial Accounting Standards. The Accounting Review, 71 (1): 43-59.

Hanlon, G. 1994. The Commercialisation of Accountancy: Flexible Accumulation and the Transformation of the Service Class. London, UK: Macmillan.

Hayward, M.L.A., Boeker, W. 1998. Power and Conflicts of Interest in Professional Firms: Evidence from Investment Banking. Administrative Science Quarterly, 43 (1): 1-22.

Il Sole 24 Ore, Parmalat alla conquista del mondo, 25/02/1992.

Jain, A.K. 2001. Corruption: A Review. Journal of Economic Surveys, 15 (1): 71-121.

Johnson, T. 1972. Professions and Power. London, UK: Macmillan.

Ke, B., Yu, Y. 2006. The Effect of Issuing Biased Earnings Forecasts on Analysts' Access to Management and Survival. Journal of Accounting Research, 44 (5): 965-999.

Kindleberger, C.P., Aliber, R.Z. 2005. Manias, Panics, and Crashes, Hoboken. New York, NY: John Wiley and Sons.

Kinney, W.R., Palmrose, Z.V., Scholz, S. 2004. Auditor Independence, Non-Audit Services, and Restatements: Was the U.S. Government Right? Journal of Accounting Research, 42 (3): 561 588.

Klimentchenko, D.A. 2009. Myth of Auditor Independence. University of Illinois Law Review: 12751299.

Knapp, M.C. 1985. Audit Conflict: An Empirical Study of the Perceived Ability of Auditors to Resist Management Pressure. The Accounting Review, 60 (2): 202-211. 
Knechel, W.R., Sharma, D.S. 2012. Auditor-Provided Nonaudit Services and Audit Effectiveness and Efficiency: Evidence from Pre- and Post-SOX Audit Report Lags. Auditing: A Journal of Practice \& Theory, 31 (4): 85-114.

Lander, M.W., Koene, B.A.S., Linssen, S.N. 2013. Committed to Professionalism: Organizational Responses of Mid-tier Accounting Firms to Conflicting Institutional Logics. Accounting, Organizations and Society, 38 (2): 130-148.

Lawrence, T., Suddaby, R., Leca, B. 2009. Institutional Work: Actors and Agency in Institutional Studies of Organizations. Cambridge, UK: Cambridge University Press.

Leicht, K.T., Fennell, M.L. 2001. Professional Work: A Sociological Approach. Malden, MA: WileyBlackwell.

Levitt, A. 2000. Renewing the Covenant with Investors. Speech at New York University Center for Law and Business. 10/05/2000.

Lim, T. 2001. Rationality and Analysts' Forecast Bias. Journal of Finance, 56 (1): 369-385.

Lin, H-W., McNichols, M.F. 1998. Underwriting Relationships, Analysts' Earnings Forecasts and Investment Recommendations. Journal of Accounting and Economics, 25 (1): 101-127.

Lord, A.T. 1992. Pressure: A Methodological Consideration for Behavioral Research in Auditing. Auditing: A Journal of Practice \& Theory, 11 (2): 89-108.

Louwers, T.J. 1998. The Relation between Going-Concern Opinions and the Auditor's Loss Function. Journal of Accounting Research, 36 (1): 143-156.

MacDonald, K.M. 1995. The Sociology of the Professions. London, UK: Sage.

Macintosh, N., Quattrone P. 2010. Management Accounting and Control Systems: An Organizational and Sociological Approach, 2nd Edition. Chichester: UK: John Wiley \& Sons Ltd.

Macy, J., Sale, H.A. 2003. Observation on the Role of Commodification, Independence, and Governance in the Accounting Industry. Villanova Law Review, 48: 1167.

Matsumoto, D.A. 2002. Management's Incentives to Avoid Negative Earnings Surprises. Accounting Review, 77 (3): 483-514.

Merrill Lynch, 2002. Company Update. 05/12/2002. 
Merton, R.K. 1957. Social Theory and Social Structure. New York, NY: Free Press.

Michaely, R., Womack, K.L. 1999. Conflict of Interest and the Credibility of Underwriter Analyst Recommendations. Review of Financial Studies, 12 (4): 653-686.

Moore, D.A., Tetlock, P.E., Tanlu, L., Bazerman, M. 2006. Conflicts of Interest and the Case of Auditor Independence: Moral Seduction and Strategic Issue Cycling. Academy of Management Review, 31 (1): 10-29.

Muzio, D., Brock, D.M., Suddaby, R. 2013. Professions and Institutional Change: Towards an Institutionalist Sociology of the Professions. Joumal of Management Studies, 50 (5): 699- 721.

National Fraud Authority, The. 2013. Annual Fraud Indicator. June 2013.

New York Times, The. 2001. Enron Tries To Dismiss Finance Doubts. 24/10/2001.

New York Times, The. 2012. The Spreading Scourge of Corporate Corruption. 10/07/2012.

O’Brien, P.C., McNichols, M.F., Hsiou-Wei, L. 2005. Analyst Impartiality and Investment Banking Relationships. Journal of Accounting Research, 43 (4): 623-650.

Pache, A., Santos, F. 2010. When Worlds Collide: The Internal Dynamics of Organizational Responses to Conflicting Institutional Demands. Academy of Management Review, 35 (3): 455-476.

Pache, A., Santos, F. 2013. Embedded in Hybrid Contexts: How Individuals in Organizations Respond to Competing Institutional Logics. Research in the Sociology of Organizations, 39: 355.

Palmer, D. 2012. Normal Organizational Wrongdoing. A Critical Analysis of Theories of Misconduct in and by Organizations. New York, NY: Oxford University Press.

Parmalat Annual Report, 2000.

Public Prosecutor, Parma, Notice of Termination of Preliminary Investigations, art. 415/bis, Italy's Code of Criminal procedure (CPP).

Rex, J. 1970. Race Relations in Sociological Theory. London, UK: Routledge. 
Richardson, S., Teoh, S.H., Wysocki, P.D. 2004. The Walk-down to Beatable Analyst Forecasts: The Role of Equity Issuance and Insider Trading Incentives. Contemporary Accounting Research, 21 (4): 885-924.

Rindova, V.P., Pollock, T.G., Hayward, M.L.A. 2006. Celebrity Firms: The Social Construction Of Market Popularity. Academy of Management Review, 31 (1): 50-71.

Robinson, T. 1978. In Worlds Apart: Professionals and their Clients in the Welfare State. Bedford Square Press.

Santoro, M.A., Strauss, R.J. 2013. Wall Street Values: Business Ethics and the Global Financial Crisis. New York, NY: Cambridge University Press.

Schnatterly, K. 2003. Increasing Firm Value through Detection and Prevention of White-collar Crime. Strategic Management Journal, 24 (7): 587-614.

SEC, 2000. Final Rule: Revision of the Commission's Auditor Independence Requirements, $21 / 11 / 2000$.

SEC. 2002. All About Auditors: What Investors Need to Know.

SEC. 2003. Securities and Exchange Commission v. Parmalat Finanziaria S.p.A., Case No. 03 CV 10266 (PKC) (S.D.N.Y.), Accounting and Auditing Enforcement Release No. 1936.

Senate Governmental Affairs Committee. 2002. Rating the Raters: Enron and the Credit Rating Agencies, Hearing Before the Senate Governmental Affairs Committee, 107th Cong., S. Hrg. 107-471 (March 20, 2002) at 65-66, 122.

Sentence, Court of Milan. Tribunale di Milano, Sezione I Penale, Sentenza, N. 10465/04 R.G. n.r., N. 12473/04 + 7436/08 + 9538/05 R.G. Trib, 18/12/2008.

Sharma, A. 1997. Professional as Agent: Knowledge Asymmetry in Agency Exchange. Academy of Management Review, 22 (3): 758-798.

Sikka, P. 2009. Financial Crisis and the Silence of the Auditors. Accounting, Organizations and Society, 34 (6/7): 868-873.

Suddaby, R., Greenwood, R. 2001. Colonizing Knowledge: Commodification as a Dynamic of Jurisdictional Expansion in Professional Service Firms. Human Relations, 54 (7): 933-953. 
Suddaby, R., Greenwood, R. 2005. Rhetorical Strategies of Legitimacy. Administrative Science Quarterly, 50 (1): 35-67.

Suddaby, R., Gendron, Y., Lam, H. 2009. The Organizational Context of Professionalism in Accounting. Accounting, Organizations and Society, 34 (3-4): 409-427.

von Nordenflycht, A. 2010. What Is a Professional Service Firm? Toward a Theory and Taxonomy of Knowledge-Intensive Firms. Academy of Management Review, 35 (1): 155-174.

Welch. I. 2000. Herding among Security Analysts. Journal of Financial Economics, 58 (3): 369-396.

Westphal, J.D., Clement, M.B. 2008. Sociopolitical Dynamics in Relations between Top Managers and Security Analysts: Favor Rendering, Reciprocity, and Analyst Stock Recommendations. Academy of Management Journal, 51 (5): 873-897.

Willmott, H., Sikka, P. 1997. On the Commercialization of Accountancy Thesis: A Review Essay. Accounting, Organizations and Society, 22 (8): 831-842.

Wyatt, A.R. 2004. Accounting Professionalism - They Just Don't Get It! Accounting Horizons, 18 (1): 45-53.

Zahra, S.A., Priem, R.L., Rasheed, A.A. 2013. The Antecedents and Consequences of Top Management Fraud, Joumal of Management, 31 (6): 803-828.

Zeff, S. 2003(a). How the US Accounting Profession got where it is Today: part I, Accounting Horizons, 17 (3): 189-205.

Zeff, S. 2003(b). How the US Accounting Profession got where it is Today: part II, Accounting Horizons, 17 (4): 267-86. 